\title{
The Proceedings of the International Conference
}

on Creationism

Volume 8

Print Reference: Pages 379-388

Article 18

2018

\section{Global Deposits of in situ Upper Cambrian microbialites: Implications for a Cohesive Model of Origins}

Ken P. Coulson

San Diego Christian College

Follow this and additional works at: https://digitalcommons.cedarville.edu/icc_proceedings

Part of the Geology Commons, Paleobiology Commons, and the Stratigraphy Commons

DigitalCommons@Cedarville provides a publication platform for fully open access journals, which means that all articles are available on the Internet to all users immediately upon publication. However, the opinions and sentiments expressed by the authors of articles published in our journals do not necessarily indicate the endorsement or reflect the views of DigitalCommons@Cedarville, the Centennial Library, or Cedarville University and its employees. The authors are solely responsible for the content of their work. Please address questions to dc@cedarville.edu.

Browse the contents of this volume of The Proceedings of the International Conference on Creationism.

\section{Recommended Citation}

Coulson, K.P. 2018. Global deposits of in situ upper Cambrian microbialites-Implications for a cohesive model of origins. In Proceedings of the Eighth International Conference on Creationism, ed. J.H.

Whitmore, pp. 373-388. Pittsburgh, Pennsylvania: Creation Science Fellowship. 


\title{
GLOBAL DEPOSITS OF IN SITU UPPER CAMBRIAN MICROBIALITES- IMPLICATIONS FOR A COHESIVE MODEL OF ORIGINS
}

Ken P. Coulson, San Diego Christian College, Department of Science, 200 Riverview Pkwy, Santee, CA 92071 USA, ken.coulson@sdcc.edu

\begin{abstract}
The existence of in situ microbialites of biological origin located in upper Cambrian rocks in western Utah presents some problems for creationists as they seek to define the boundary that separates pre-Flood deposits from those that were deposited during the Flood event itself. These microbialites are extensive in nature, covering an area of at least $2600 \mathrm{~km}^{2}$, and are stacked one atop the other in multiple beds that span a thickness of at least $300 \mathrm{~m}$, but could be as thick as several $\mathrm{km}$ (intercalated between wackestone wedges). Other microbialites found throughout similar upper Cambrian rocks in Nevada and California are most likely representative of those in western Utah. Upper Cambrian microbialite beds have also been described from other areas in North America that circumscribe what appears to be the ancient coast of the North American craton associated with Laurentia. A total of 24 different locations span North America starting in Newfoundland, traveling down to the New York area, crossing the southern United States to Texas, then moving over to the region around Utah, California and Nevada, before continuing the trail northward through Idaho, Alberta and on into the Northwest Territories of Canada. If these microbialites indeed are in situ, then they represent vast environments that require time frames greater than the one-year period of Noah's Flood.
\end{abstract}

\section{KEY WORDS}

stromatolite; microbialite; pre-Flood; Flood-boundary; Cambrian; creation

\section{INTRODUCTION}

\section{Creationist Background and Relevance}

For creationists, the approximate location of the pre-Flood/Flood boundary, as well as the Flood/post-Flood boundary are important topics that have far-reaching applications for creationist modelbuilding in general. Reasoning that rejects such a boundary (or boundaries) usually stems from a belief that the Noahic Flood of Genesis 6-9 was merely local. If, however, the Flood of Noah was global in scope, as most creationists believe, then there should exist plenty of geological evidence to support this belief. Moreover, since most creationists interpret the geological events associated with the Flood in terms of "normal, natural processes," then the geological evidence should be subject to scientific enquiry. Starting from these assumptions and using the biblical account as a guide, most creationists therefore assume that the onset and duration of the Flood was geologically rapid and catastrophic, taking about a year from its inception to its end. Since the normal rules of science apply, the evidence for this boundary should therefore be detectable and measurable.

Most creation geologists believe that the Precambrian/Cambrian boundary, or very close to this boundary, is representative of the pre-Flood/Flood boundary (Austin and Wise 1994; Dickens and Snelling 2008; Dickens 2017). Others disagree (Oard 2013), but the consensus favors this interpretation. Arguments supporting a pre-Flood/Flood boundary at the Precambrian/Cambrian boundary are quite persuasive and make sense given the kinds of processes one might assume were at work during this period. Perhaps the most persuasive argument is the wide spread existence of a surface of erosion called "the Great Unconformity." This surface of erosion occurs at many localities around the world, and its existence is supported by both creationists and secularists alike
(Austin and Wise 1994; Dickens and Snelling 2008; Peters and Gaines 2012; Dickens 2017). Another persuasive argument points to the great disparity that exists between the fossil record as it appears both below and above this boundary. Fossils, especially metazoans, are rare in Precambrian rocks, while abundant in those that belong to Cambrian time. Catastrophic burial during the Flood seems a robust explanation for the existence of almost perfectly fossilized fauna all over the world. For most creationists then, the Precambrian/Cambrian Flood boundary is an obvious choice that needs no further consideration. This paper identifies some very real challenges to this assumption.

\section{Geologic Background}

From a secular perspective, the western continental margin of Laurentia is thought to have formed during the Late Proterozoic rifting of Rodinia. According to Miller et al. (2003, p. 58), lower Paleozoic strata of the eastern Great Basin were deposited on a collapsing carbonate platform that provided thousands of meters of accommodation space. The Cambrian/Ordovician Orr and Notch Peak Formations as well as the Ordovician House Limestone lie within these sediments in what is now southwestern Utah. Central to this discussion is the microbialite-bearing Notch Peak Formation which has been divided into three mappable members: the Hellnmaria, Red Tops and Lava Dam (Fig. 1).

\section{Microbialite Definition}

For the purpose of this paper, the definition of Burne and Moore (1987, p. 241-242) will be used: "Microbialites are organosedimentary deposits that have accreted as a result of a benthic microbial community trapping and binding detrital sediment and/or forming the locus of mineral precipitation." Caution must, however, be exercised when working with this definition due to 


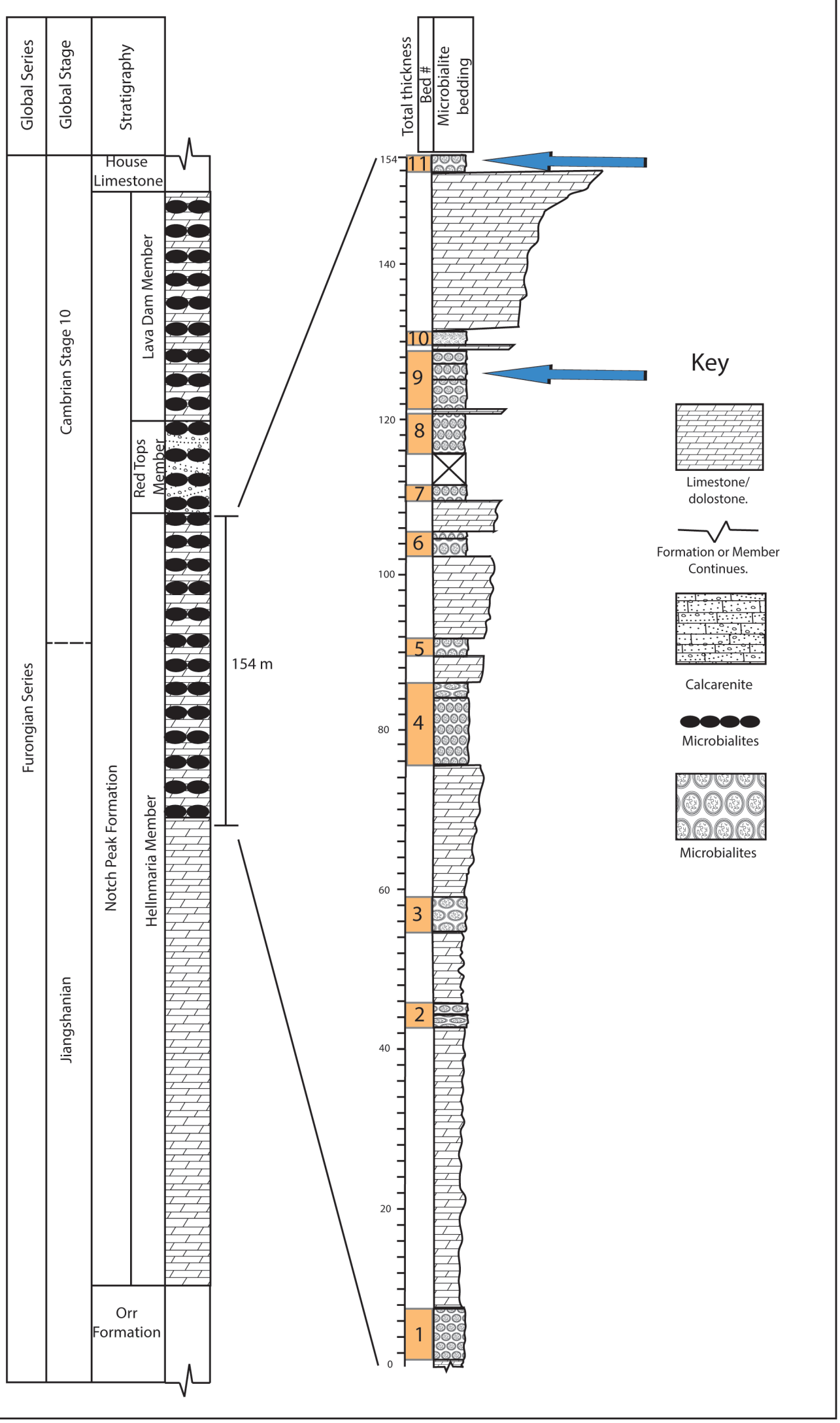

Figure 1. Stratigraphic column of the Notch Peak Formation, adapted and simplified from Hintze et al. (1988). Tapered Limestone/dolostone sections communicate a general coarsening upward trend. Arrows indicate beds 9 and 11. Note multiple layers of microbialites in both the Red Tops Member and the Lava Dam Member. Figure modified and used with permission from SEPM, Coulson and Brand (2016). 
the confusion associated with abiotic versus biotic processes. A microbialite is technically the umbrella term used for three basic morphologies: stromatolites, thrombolites and dendrolites. Although Burne and Moore's definition precludes abiotic processes, it is elsewhere assumed. Consider this definition of a stromatolite by Semikhatov et al. (1978, p. 992), "Stromatolites are laminated, lithified, sedimentary growth structures that accrete away from a point or limited surface of attachment. They are commonly, but not necessarily, of microbial origin and calcareous composition." Note that although a microbial origin is thought most likely, it isn't a requirement. This is also true for thrombolites and dendrolites.

\section{Microbialite Growth Processes}

Microbialites accrete at a sub-laminar to laminar level using three general processes. 1. There is a purely mechanical interaction between benthic, microbial communities and detrital grains of sediment. Here, the sticky EPS sheaths of microbes trap and bind sediment grains. 2. Precipitation of calcite by purely biological factors due to chemical changes associated with photosynthesis. 3 . Precipitation of calcite by purely inorganic factors due to changes in the environment.

\section{Growth rates}

The rate of microbialite growth has been calculated at between $5 \mathrm{~mm}$ a year for microbialites at Shark Bay, Western Australia (Playford 1980) to as high as $36.5 \mathrm{~cm}$ a year for modern forms growing in Bermuda (Gebelein 1969) and an equally high rate of $36.5 \mathrm{~cm}$ a year for forms found in Bahamian tidal channels (Reid et al. 2000). Many factors, however, can influence this rate of growth, and so a growth rate in and of itself should not be characteristic of growth rates in general. For example, the Shark Bay microbialites seem to represent an exhausted ecosystem (Playford 1980, p. 73). Proximal sea level has been dropping consistently for quite some time, and many microbialites now sit within the supratidal zone, completely stranded from a prior, sub-aqueous existence. Since no real opportunity for further growth exists at Shark Bay, the very low rate of growth for these forms should not be used as a proxy for microbialites in a more favorable environment. The modern forms growing in sand-laden channels in the Bahamas, can accrete at 1 lamination per day (365 a year at approximately $1 \mathrm{~mm}$ per lamination = approximately $36.5 \mathrm{~cm}$ per year), but never actually maintain this rate due to factors such as matt type, burial, lithification, and scouring by sand (Reid et al. 2000). More recently, Berelson et al. (2011) conducted an experiment on silicon microbialites growing in a pond at Yellowstone National Park. They were able to grow a microbialite from scratch and were therefore able to verify a high growth rate of $5.7 \mathrm{~cm}$ a year. Eagan and Liddell (1997, p. 302) predicted an extremely high rate of growth for ancient microbialites of between $37 \mathrm{~cm}$ to $60 \mathrm{~cm}$ a year.

These varying rates, although quite diverse, seem to reflect the environment in which the microbialites grew or are growing. Supratidal forms predictably do not really grow at all; sub-tidal forms that are subject to constant erosion and burial, although growing rapidly at times, tend to lose their newly acquired width and height to the erosive activity of sand. On the other hand, the forms found in Cambrian rocks by Eagan and Liddell (1997) seem to have been growing in a favorable environment - hence the high growth rates. The microbialites studied in this paper are temporally and geographically very close to those studied by Eagan and Liddell (1997), and thus serve as an environmental proxy that suggests high rates of microbialite growth.

From a creationist perspective, given extremely favorable conditions of growth, it is not implausible to consider growth rates on the order of several meters per year for the Hellnmaria microbialites.

\section{METHODS}

Seven sections of the Hellnmaria Member were measured, described and analyzed (Fig. 2). Samples were collected by hand, but many were drilled from microbialite-rich surfaces. Two microbialite beds, correlative over the entire seven sections, were specifically chosen for high-resolution research and subject to techniques in microscopy, Scanning Electron Microscopy (SEM), X-ray diffraction (XRD) and Energy Dispersive X-ray Spectroscopy (EDS).

Literature research was also adopted for the purpose of correlating the Hellnmaria forms with others throughout North America, as well as globally.

\section{RESULTS}

\section{Hellnmaria Microbialites}

Hintze et al. (1988) bundle all of the Hellnmaria microbialites into a single package of strata that spans the upper $154 \mathrm{~m}$ of the Hellnmaria Member. We re-measured this segment of the type section being especially attentive to specific microbialite beds, bed thicknesses and general microbialite characteristics. We found eleven distinct microbialite-bearing beds separated by intervening wackestone-grainstone intervals that span the upper $154 \mathrm{~m}$ of the Hellnmaria Member (Fig. 1). Due to uplifting, all of the blocks within the study area have a general dip of about $10^{\circ}$ towards the southeast. As a result, we could only trace these beds over a geographic area of approximately $20 \mathrm{~km}^{2}$ before they dipped down into the subsurface. Brand et al. (2012) were able to trace some of these upper Hellnmaria microbialites to the Drum Mountains in the North and the Wah Wah mountains in the south, providing a total areal distribution of over $2600 \mathrm{~km}^{2}$. Based on the work of others, it is likely that the total distribution for the Notch Peak microbialites as a whole reaches to several tens of thousands of square km (Hintze et al. 1988; Miller et al. 2003).

Bed 9 (Fig. 1) is a $5-14$ meter-thick microbialite-bearing unit that exhibits a change in morphology as seen in vertical crosssection (Fig. 2). Microbialites change from round at the bottom of the bed to elongate in the middle of the bed and then back to round again at the top of the bed (Fig. 3). Remarkably, each of these changing morphologies can be distinguished at all seven outcrop locations (Fig. 2), with the microbialites in the elongate layer exhibiting a consistent $140^{\circ} / 320^{\circ}$ bearing (Fig. 3C). At most of the outcrop locations, coalescing round microbialites are found both beneath and above the strongly elongate layer (Fig. 3A and B). These observations led us to hypothesize the existence of a bidirectional hydrodynamic system that was chiefly at work during the deposition of the elongate layer (Coulson et al. 2016). This interpretation is reinforced by the sedimentological data; micrite found in the interspaces of the lower, round microbialites, as well as in the round forms at the top of the bed indicate the absence 


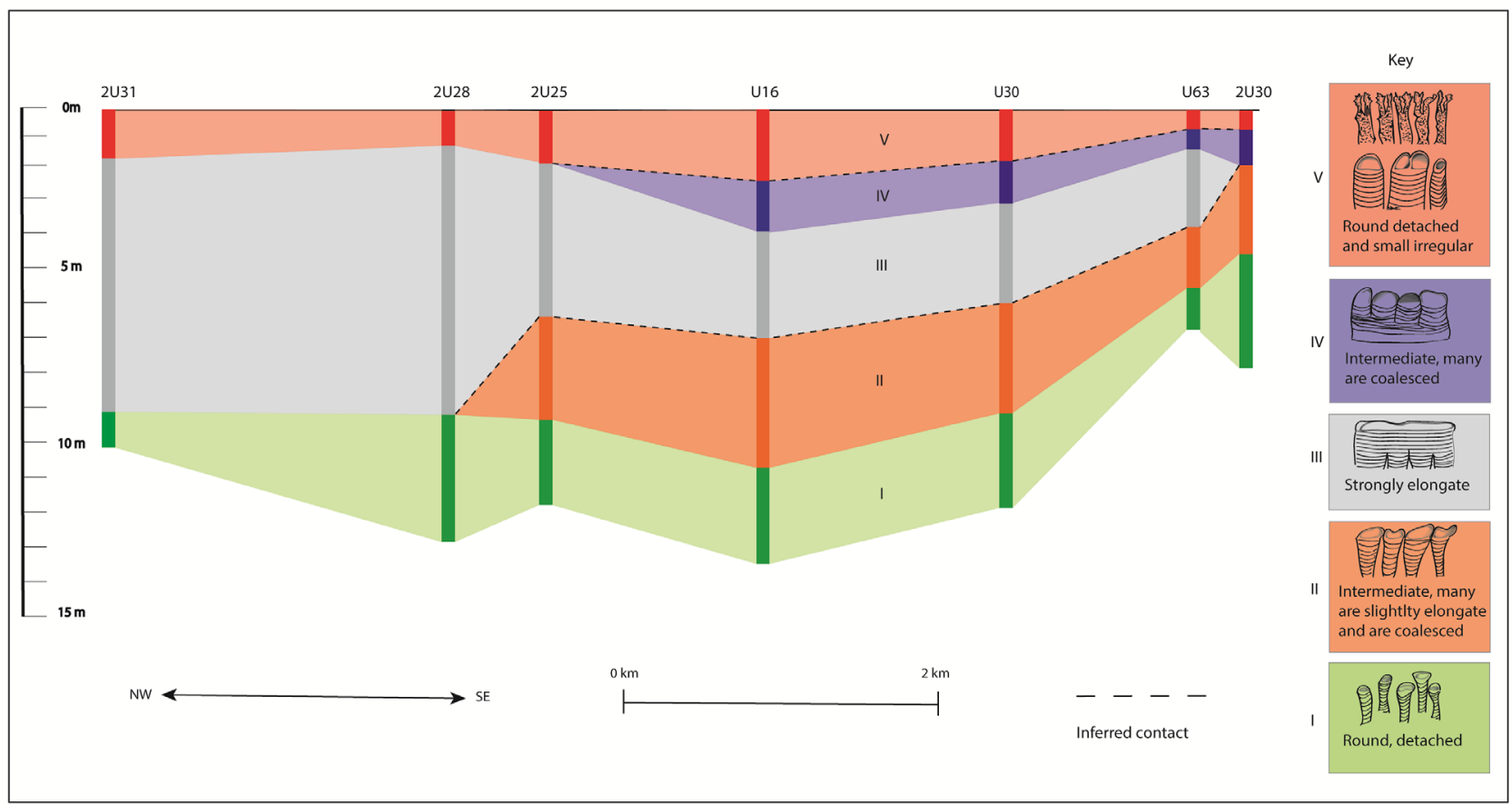

Figure 2. Cross-sectional view of bed 9 showing a correlation for each morphology across the research area. Datum line is set at the top of the bed. A line was drawn between the two most distance outcrop locations and the rest of the locations were superimposed onto that line. Reprinted by permission from Springer Customer Service Center: Springer, Facies, Microbialite elongation by means of coalescence: an example from the middle Furongian (upper Cambrian) Notch Peak Formation of western Utah, Ken P Coulson and Leonard R Brand, C) , 2016, advance online publication, $30^{\text {th }}$ of April 2016, doi.org/10.1007/s10347-016-0469-5
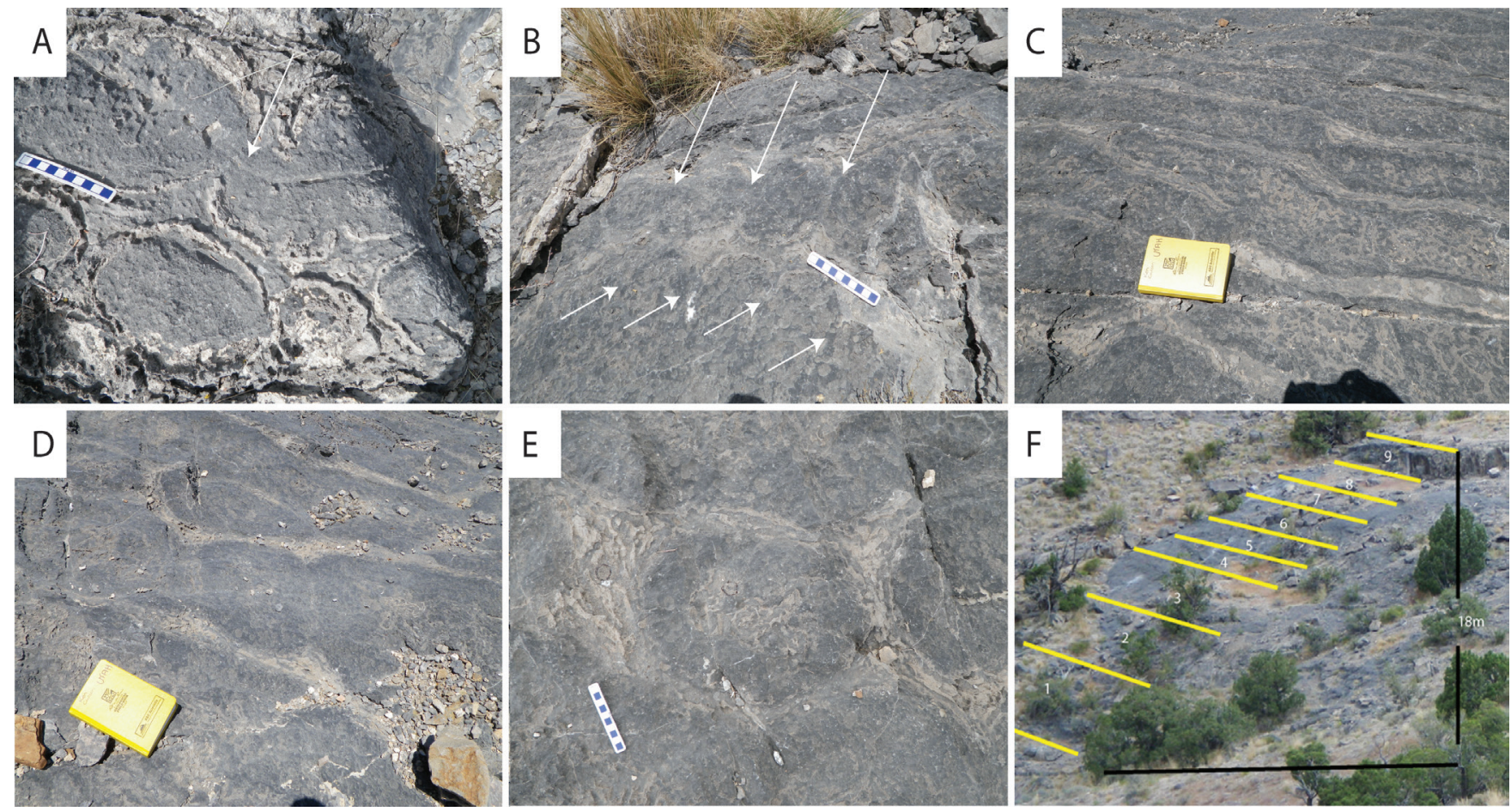

Figure 3. All images are in plan-view. A - E show a changing microbialite morphology as one traverses up-section. Arrows represent coalescing microbialites. Forms start out round at the bottom of the section, then begin to align into rows a meter or so up-section (B). Another half meter or so up-section the forms become strongly elongate $(\mathrm{C})$, with many elongate microbialites reaching lengths of $5 \mathrm{~m}$. The elongate layer within the bed can be correlated for many tens of square kilometers and is anywhere from 1.5 to $8 \mathrm{~m}$ thick (see figure 2). D and E show the elongate forms widening and then separating into large, round forms at the top of the bed. In F, a typical outcrop is represented and broken into layers, each of which represent some change in morphology. At this outrcop, round microbialites are found at 1 , and 6 , and 7 . The strongly elongate layer is found at 3 . The entire bed is about 14 meters thick at this location. Reprinted and adapted by permission from Springer Customer Service Center: Springer, Facies, Microbialite elongation by means of coalescence: an example from the middle Furongian (upper Cambrian) Notch Peak Formation of western Utah, Ken P Coulson and Leonard R Brand, (C) , 2016, advance online publication, 30 ${ }^{\text {th }}$ of April 2016, doi.org/10.1007/s10347-016-0469-5 
of environmental turbulence. Packstones and grainstones in the interspaces of the elongate forms indicate a more aggressive flowregime. In our model, tightly packed round microbialites began to coalesce with their neighbors at the introduction of a bi-directional flow regime (Coulson et al. 2016). As a result, coalescence occurred parallel to flow constructing linear groups of laterally linked forms (Fig. 3B). Strongly elongate structures naturally followed (Fig. 3C). The round forms at the top of the bed resulted from the removal of this bi-directional hydrodynamic system (Fig. 3D and E). This process of coalescence has a modern analogue in the microbialites at Shark Bay in Western Australia where the same process occurs and for the same reasons (Logan 1961; Coulson et al. 2016).

Bed 11 (Fig. 1) is a 1 to $3 \mathrm{~m}$ thick microbialite-bearing unit that contains a tightly packed field of round to sub-round microbialites (Fig. 4). Microbialite meso-scale fabric is best described as stromatolitic, but many forms have a large central thrombolitic core composed of mini-stromatolites (Fig. 4B and C). Diameters vary from about $40-70 \mathrm{~cm}$, and due to the fissile nature of the overlying strata, are very well exposed in plan-view at multiple locations (Fig. 5A). Heights vary from $20 \mathrm{~cm}$ to about $70 \mathrm{~cm}$ and in cross-section widen slightly towards the top (Fig. 4B and D; Fig. $5 \mathrm{~B})$. As with bed 9 , we could only trace this bed over a geographic area of approximately $20 \mathrm{~km}^{2}$, although its areal extent is much greater (Brand et al. 2012). All of the microbialites we saw (over five hundred) are upright and in growth position when exposed in cross-section (Fig. 5). This particular bed was so distinctive that even after travailing a valley to get to the next bed several $\mathrm{km}$ away, its location within the member could be accurately predicted to within a few vertical meters. Within many of these microbialites were found what we interpreted to be sponge-spicule networks (Fig. 6). These networks represent the remains of siliceous sponges that calcified before postmortem decay, leaving the isolated spicules 'floating' in what may have originally been a fleshy matrix (Coulson and Brand 2016). Networks typically do not exceed a few $\mathrm{cm}$ in size, with many not exceeding $1 \mathrm{~cm}$, and appear in growth position over micritic bands (Fig. 7). Together, the micritic bands and sponge-spicule networks produce the familiar concave-down laminations that typically define protozoan microbialites (Fig. 4B and D; Fig. 5).

Based on the presence of well-washed, inter-columnar grainstones deposited between the microbialites of bed 11 (Fig. 4F), we suggested that these forms grew in a shallow, sub-tidal environment (Coulson and Brand 2016). Microbial biofilms first colonized and stabilized the underlying substrate. As a result of continued microbial trapping and binding of lime mud and/or precipitation of micrite, the meso-fabric took on a stromatolitic texture. This initial rigid microbialite served as a suitable substrate for early sponge attachment. The microbial communities and the sponges then competed for space by encrusting each other. This regular organization eventually led to the construction of a columnar 'stromatolite.'

Beds 9 and 11 exhibit many factors consistent with an energetic, shallow, sub-tidal marine environment brimming with aquatic life. The grainstones found intercalated between the microbialite beds, as well as those found in the spaces that separate individual microbialites are filled with trilobite hash (Fig. 4F). Other invertebrate fossils such as gastropods, sponges and mollusks, can also be found throughout the entire upper $154 \mathrm{~m}$ of the Hellnmaria Member.

\section{Upper Cambrian Microbialites in North America}

Lee et al. (2015) constructed a table of all known upper Cambrian microbialites from around the world. They described a total of 31 geographically distinct sites in North America where upper Cambrian microbialites can be found. Each of the papers referenced by Lee et al. (2015) were perused in order to differentiate in situ microbialites from those of allochthonous origin. Of those 31 sites, 24 were interpreted by the authors to represent areas of in situ growth, conclusions with which I agree. Data for the other 7 sites was either limited or represented allochthonous deposits (Fig. 8). In many of these locations, microbialites were found at multiple stratigraphic horizons. For example, in the Canadian Rockies, microbialites can be found at 8 different horizons (Aitken 1967). In northern Utah, microbialites can be found at 6 different horizons (Saltzman et al. 2004). In Maryland, microbialites can be found at 12 different horizons (Demicco 1985). In Nevada, microbialites can be found at 3 different horizons (Osleger and Montañez 1996). Many of these microbialite beds are also quite extensive, covering several tens of square $\mathrm{km}$ in area (Srinivasan and Walker 1993), and many have bed thicknesses of multiple meters (Pratt 1984; Kennard and James 1986). Interestingly, almost all of these locations seem to span the southern United States, from New York to the region around Utah, California and Nevada, and then continue the trail northward through Idaho, Alberta and into the Northwest Territories of Canada. Of these locations, almost all of them are stratigraphically located above Cambrian sandstones that themselves are thought representative of erosional processes related to the Great Unconformity.

\section{Upper Cambrian Microbialites globally}

Although North America boasts some of the best Cambrian microbialites in the world, it is not the only place where abundant Cambrian microbialites can be found. Russia and China also boast plentiful microbialite beds, with lessor distributions found in Australia, Iran, Korea, Argentina, Kyrgyzstan and even Antarctica (Lee et al. 2015) (Fig. 9).

\section{Location of the Great Unconformity in Utah}

The location of the Great Unconformity is best delineated by the presence of the detrital sandstones that unconformably overlie the erosive surface itself (Fig. 8). The Tapeats Sandstone in the Grand Canyon is perhaps the go-to place for creationists seeking to describe, understand and showcase this underlying erosive surface. The Tapeats Sandstone and its related formations are regional in scope, extending over much of present day North America (Peters and Gaines 2012). The correlative formations for the Tapeats Sandstone in and around Utah are known as the Tintic Quartzite in central Utah, the Geertsen Canyon Quartzite in northern Utah, and the Prospect Mountain Quartzite in southern Utah (Yonkee et al. 2014). This latter Formation underlies the Notch Peak Formation, with many exposures showing a clear contact between the Prospect Mountain Quartzite and overlying limestones (Miller and Evans 2012). If we are to use the Cambrian sandstone deposits associated with the Great Unconformity as indicative of the Great Unconformity itself, then the Notch Peak Formation, along with its 

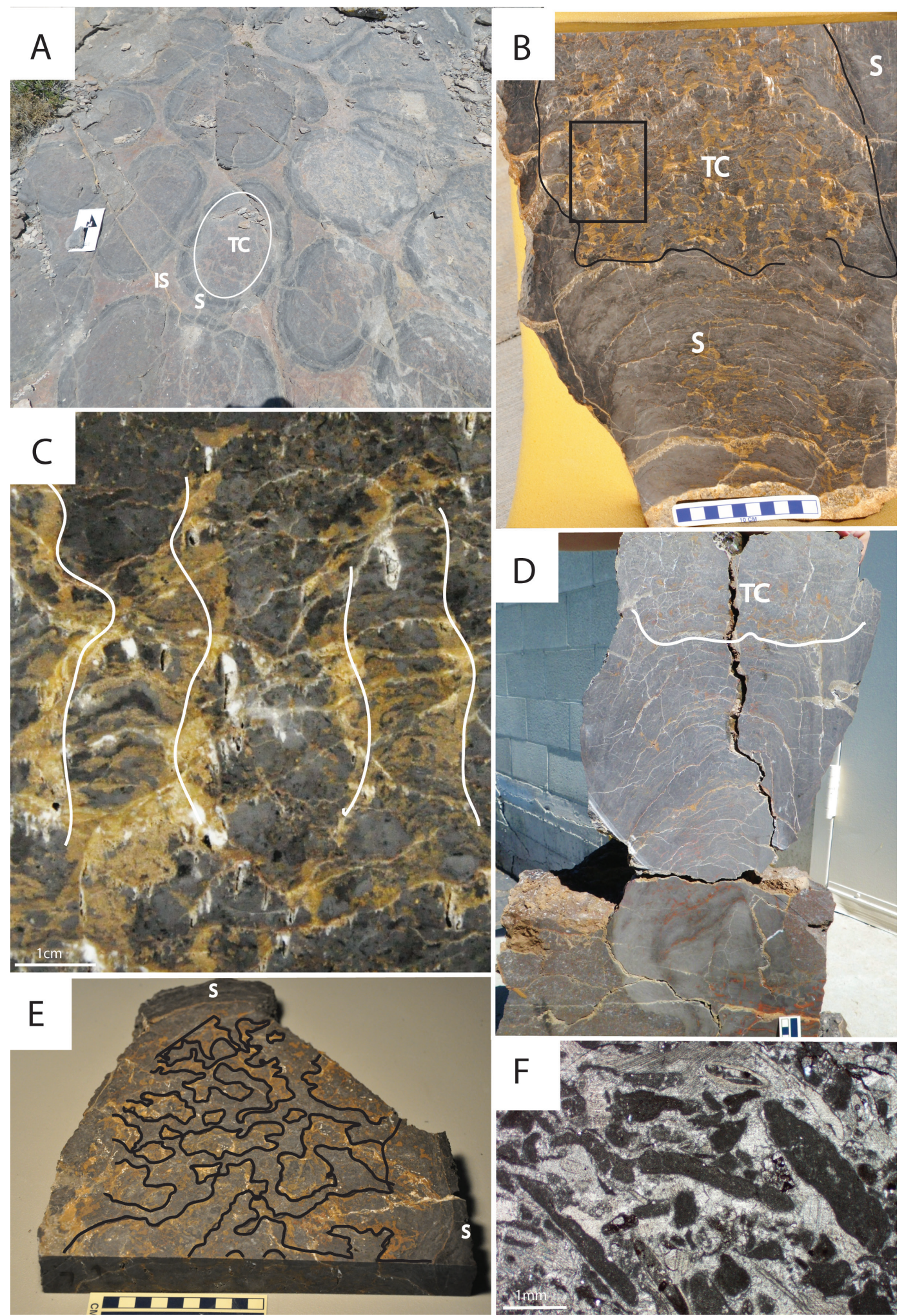

Figure 4. Macro and meso-scale features of bed 11. Abbreviations: $\mathrm{S}=$ stromatolite; IS = interspace; TC = Thrombolitic Core. A. Large, round microbialites are tightly packed with respect to each other, a feature that is common throughout the entire bed. B. An in-situ microbialite that was pulled directly from its growth position in bed 11 (see figure 5D). Notice the concave-down laminations middle to bottom, as well as thrombolitic core, middle to top. These thrombolitic cores contain mini-stromatolites (the black square in B is expanded in C). D. An in-situ microbialite that was also pulled directly from its growth position in bed 11 (see figure 5D). The microbialite was taken back to the lab and cut longitudinally through the medial plane. Again, notice concave-down laminations as well as the limestone clast upon which the form grew. Cm scale at bottom of image. E. A similar microbialite as in $\mathrm{D}$, but this time cut transversly, revealing the maze-like structure of the mini-stromatolites. F. The interpspace between these microbialites is full of trilobite hash, mollusks, and limestone intraclasts. Figure modified and used with permission from SEPM, Coulson and Brand (2016). 


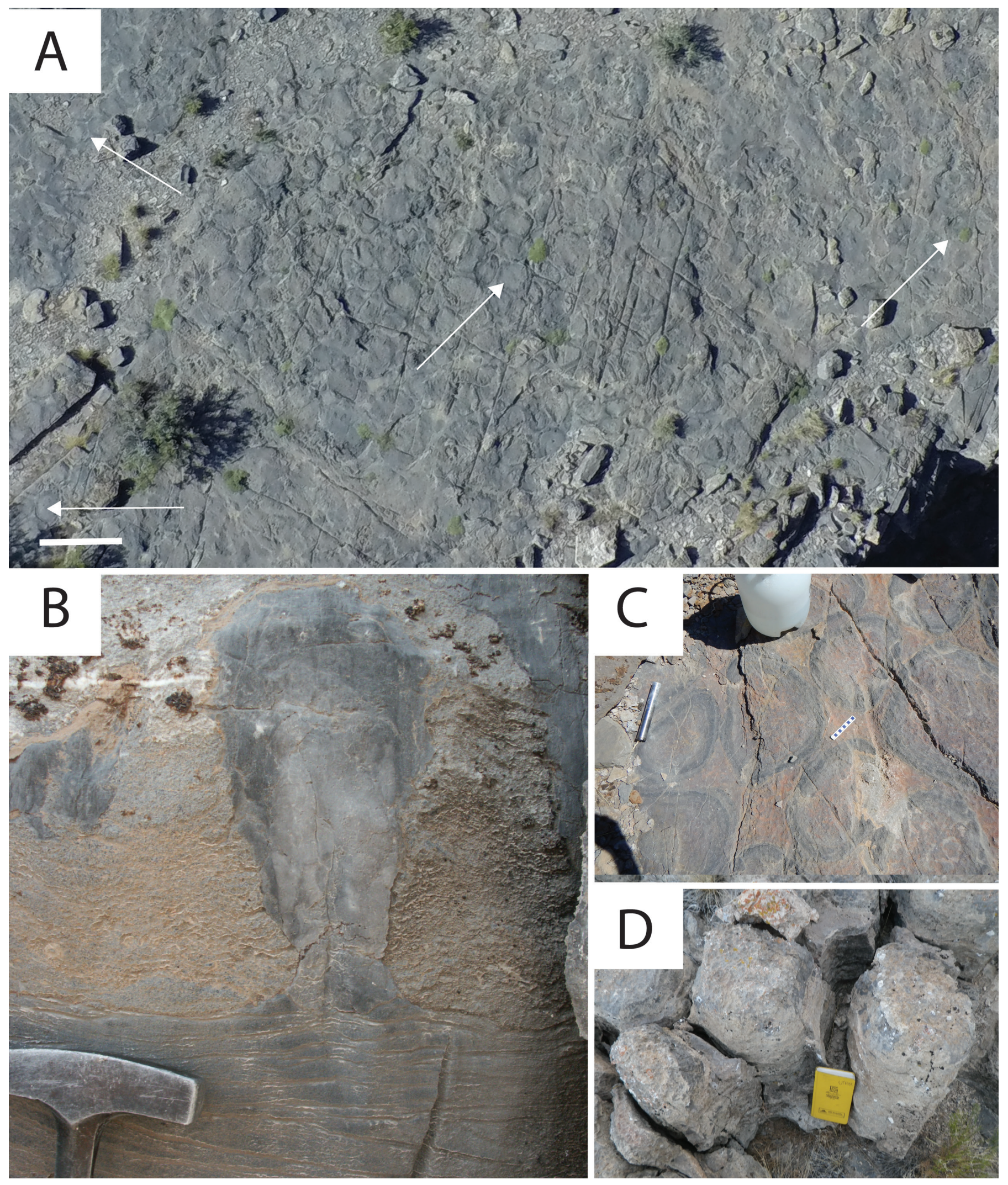

Figure 5. Macro-scale description of bed 11. A. Arial view taken from drone showing several hundred in-situ microbialites. Darker colors make it difficult to see the microbialites on the periphary of the image, but the entire surface is covered with them (arrows). Scale bar $=1 \mathrm{~m}$. Surfaces such as this were quite common for this bed at every one of the seven outcrop locations due to the fissile nature of the overlying strata. B. In-situ microbialite in growth position and attached to cross-bedded grainstone showing widening up motif. C. Close up view of some microbialites in A. D. Several forms weathering out of the bed provide a 3D glimpse at microbialites, interspaces and positions of growth. Image in 3A with thanks to Loma Linda University. Image in 3B used with thanks to Ronny Nalin. 

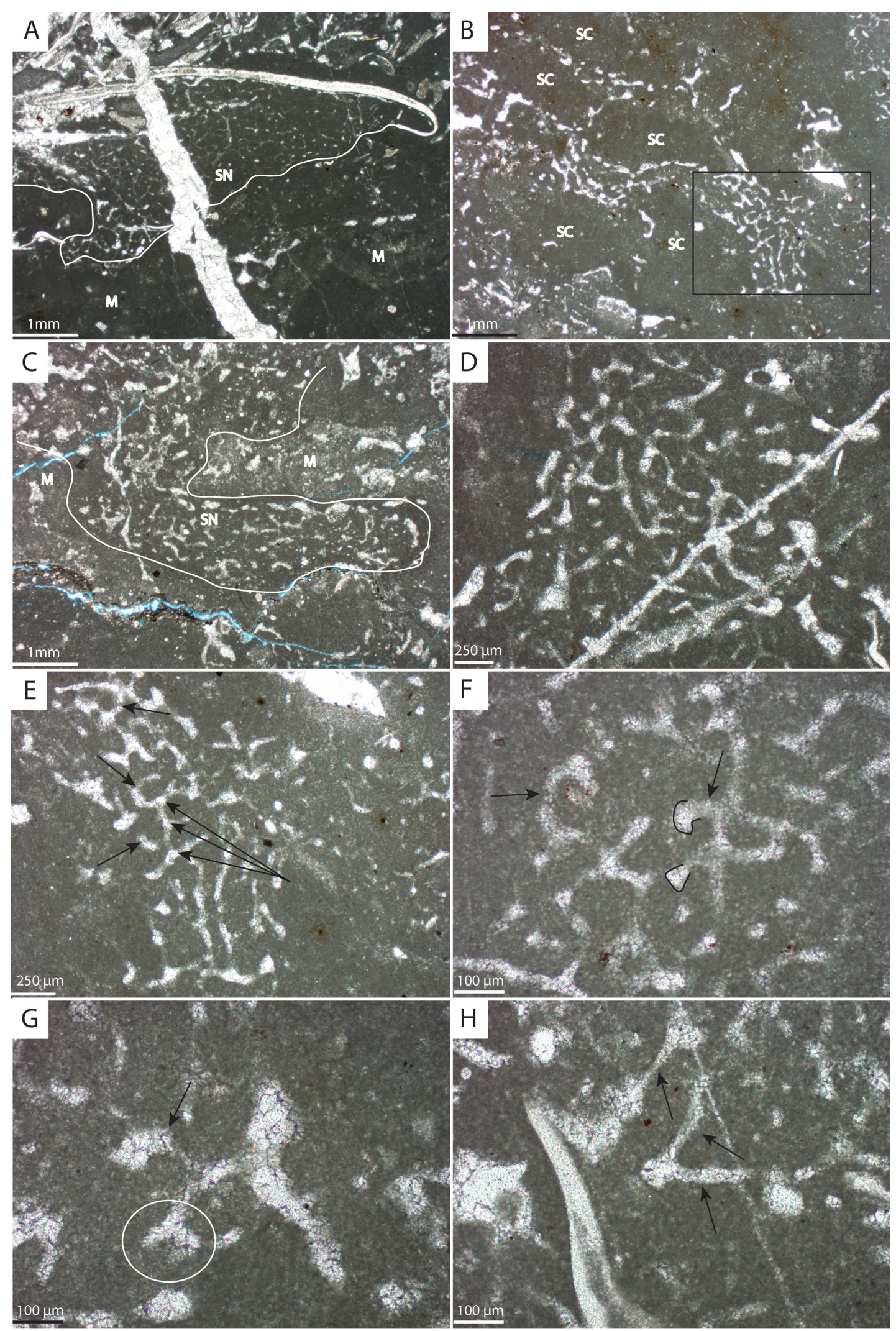

Figure 6. Spicule networks from microbialites in bed 11. All images are in cross-section. Abbreviations: $\mathrm{M}=$ micrite; $\mathrm{S}=$ sponge; $\mathrm{SC}=$ sponge cavity. A. Sponge is attached to the underside of a trilobite carapace (under the "Sheperd's Crook" which is diagnostic for trilobite carapaces). B. Spicule networks circumscribe possible sponge cavities (square enlarged in E). C and D. Two other sponge spicule networks. E. Desma-like spicules showing putative zygosis (long arrows) and curved, arcuate rays (short arrows). F. Partial network showing bulbous zygomes (outlined) and curved rays (arrows). G. Desma-like spicule showing possible gnarled zygome (circled) and curved ray (arrow). H. Spicules showing straight rays. Figure used with permission from SEPM, Coulson and Brand (2016). 


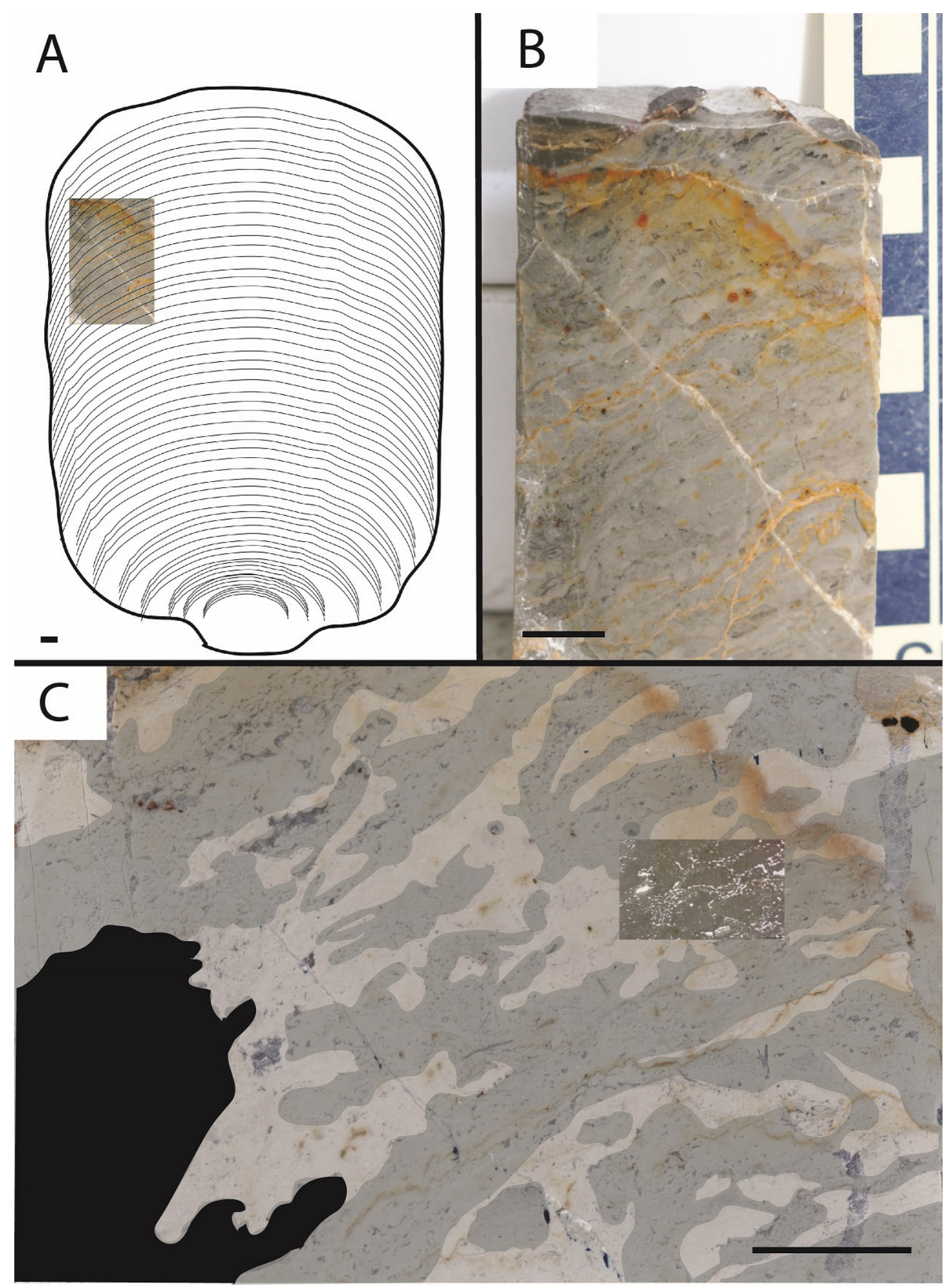

Figure 7. Meso-scale context from which to understand micro-scale spicule networks in figure 6 . All scale bars $=1 \mathrm{~cm}$. A. Idealized illustration of concave-down laminations. The small image within the illustration is the same as that in B. Position of core sample is not precise, but merely reflects its likely position within the original microbialite given the top right to bottom left orientiation of laminations. B. Core sample shown in A clearly showing mm-scale laminations. The lighter colored material is micrite while the darker colored material is representiative of linked sponge spicule networks. C. The other half of the core in B was thin-sectioned. This image is a photo of that thin-section. The darker gray color has been added to the image to show the location of sponge spicule networks in relation to the micrite (lighter gray). The blacked out section is a packstone pocket. The image center-right superimposed over the photo is the micro-graph from figure $6 \mathrm{~B}$ (although reversed), showing that these sponges were actually encrusting the microbialite and were not hash washed in from another source. Image in B modified and used with permsion SEPM, Coulson and Brand (2016). 


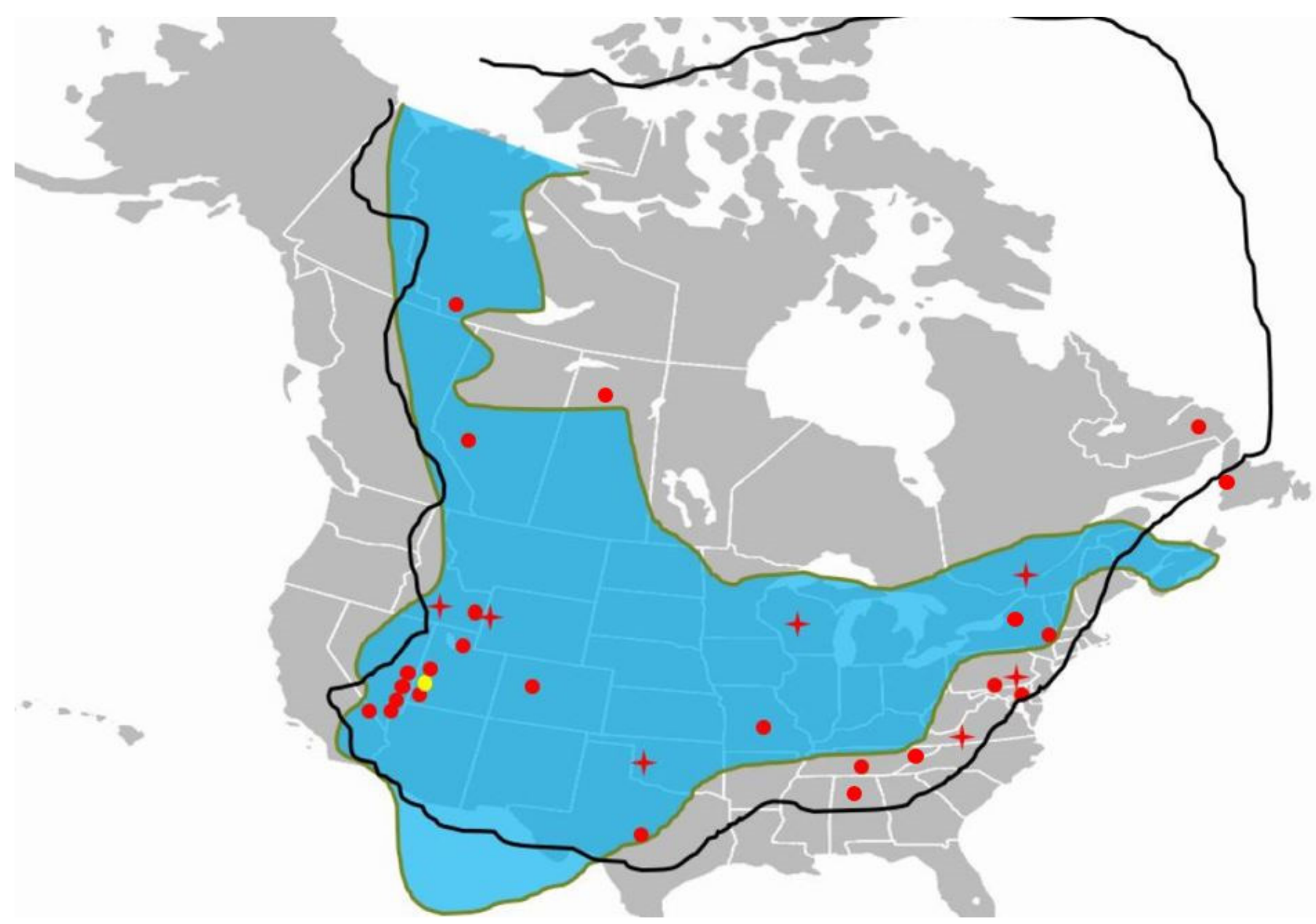

Figure 8. Cambrian microbialite distrubution throughout modern-day North America. Red dots represent in-situ forms. Red stars represent either allochthonous distributions, or their in-situ status could not be ascertained. Yellow dot represents the Notch Peak microbialites discussed in this paper. The blue L-shaped figure represents the interfingering of related Tapeats Sandstone equivelants compiled by Calvin Anderson from Cedarville University. The black line represents the outline of Laurentia. Map public domain.

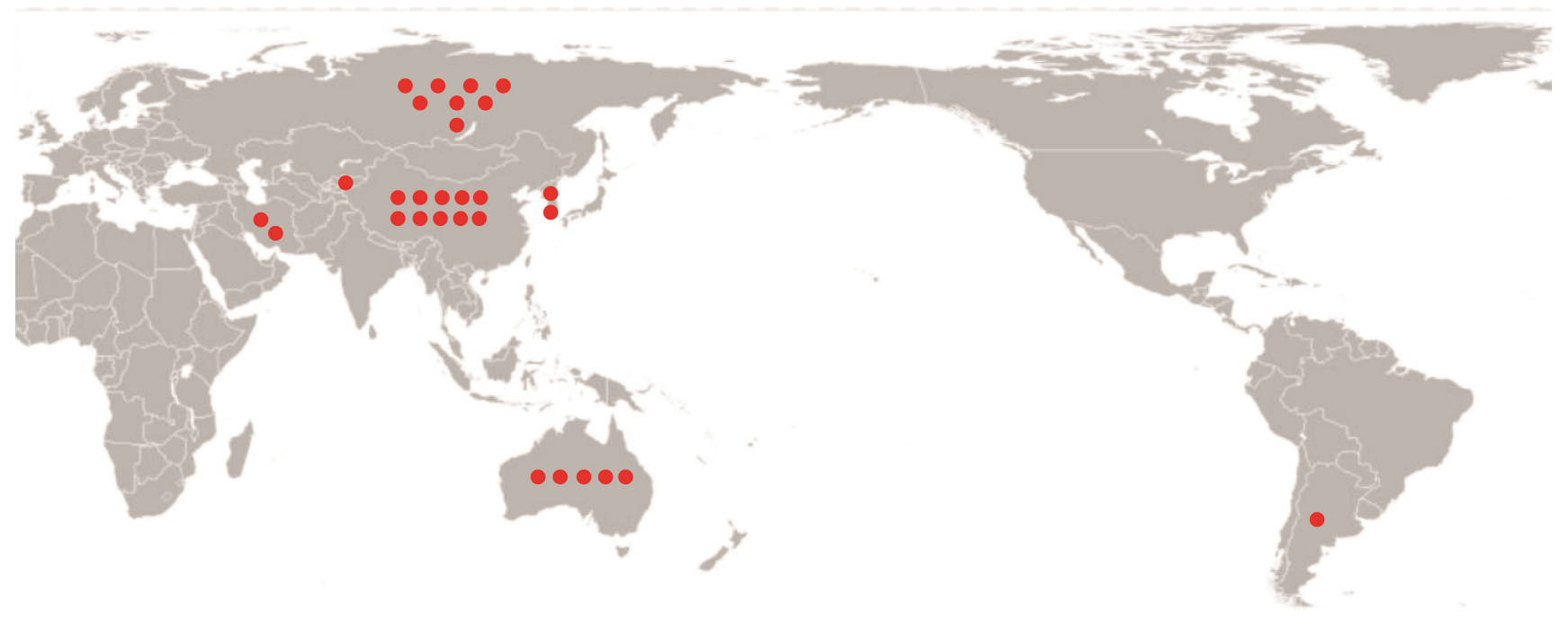

○

Figure 9. Red dots signify number of Cambrian microbialite-bearing sites representative of that country. The dots merely signify the 'number' of sites, and bear no geographically relevant information as to the location of those sites within that country. Map public domain. 
microbialites, sit stratigraphically above the Great Unconformity (Fig 8).

\section{DISCUSSION}

Due to the fissile nature of the overlying strata, the top of bed 11 is exposed at every location in the research area, and as such provides an exceptional view of several thousand forms (Fig. 5). In one area, extensive weathering allowed a $3 \mathrm{D}$ examination of the microbialites, the interspaces, and the layer of attachment (Fig. 5D). Two fully intact microbialites from this particular site were taken back to the lab for dissection. According to Wise and Snelling (2005), microbialites that widen-upward are best interpreted as in situ if the pedestal (narrow part) is found below the head (wider part). This makes sense since gravity would tend to position the heavier, wider head towards the bottom if in fact the form was transported. According to these criteria, all of the microbialites from bed 11 must be interpreted as in situ. Encrusting sponges found intercalated between concave down micritic bands further solidify these findings, signifying the presence of a complex ecosystem that spreads out for thousands of square $\mathrm{km}$. These same criteria must also apply to bed 9 , and in fact to all of the beds in the Hellnmaria Member.

Until now, most creationists have assumed that Paleozoic microbialites are rare (Purdom and Snelling 2013). When Paleozoic microbialites are encountered, they are often interpreted as having an allochthonous origin (personal communication). The reasons for this are outlined above and usually stem from a traditional understanding that places the onset of the Flood at the Precambrian/Cambrian boundary. It is evident, however, from the results of this paper that the Hellnmaria microbialites in Utah not only have a large areal distribution of several thousand square $\mathrm{km}$, they are also in situ.

All the microbialites outlined in this paper are upper Cambrian in origin, in situ, and well above the Precambrian/Cambrian boundary that in most creationist literature specifies the boundary between the pre-Flood world and the Flood event itself. Although accretion rates could potentially reach several meters of growth per year, given exceptional environmental conditions, it is extremely difficult to postulate the vast rates required to grow thick beds of microbialites of perhaps hundreds of meters in less than the oneyear period allocated for the Flood (Purdom and Snelling 2013). Of course, anything is possible, but given what we know about microbialite growth, even a liberal growth rate of several tens of meters per year (an astonishing claim in and of itself) still does not solve the problem. Add to this the environmental and ecological aspects that are recorded within the microbialite beds, and it is more logical to propose other solutions.

While working on these microbialites, many colleagues proposed that the Great Unconformity may in fact lie above these rocks instead of below them. Yet after conducting a literature review it became evident that sandstones associated with the Great Unconformity underlie not only the forms in Utah, but also most of the other locations around the ancient North American craton (Miller and Evans 2012; Peters and Gaines 2012; Yonkee et al. 2014) (Fig. 8).

\section{Possible Solutions}

A completely satisfactory solution is difficult to propose, and the solutions that follow are in no way exhaustive. The following possibilities are merely presented as a sketch that requires much in terms of corroborated thoughts and ideas.

\section{A. Allochthonous Solution}

The Cambrian rocks containing the microbialites represent preFlood environments that were pushed onto the Laurentian craton, over the Cambrian sandstones, during the Flood. In this scenario, although the individual microbialites are in situ, the entire deposit as a whole is allochthonous. This option has the advantage of retaining a Precambrian/Cambrian Flood boundary. There are problems with this option, most evident of which is the lack of geologic evidence supporting such a catastrophic movement of enormous land masses. Blocks that are hundreds and even thousands of square $\mathrm{km}$ in size and perhaps several $\mathrm{km}$ thick should leave ample evidence such as crumpling and low-angle thrust faults (Wise and Snelling 2005). Yet all of the formations spanning the lower Cambrian through upper Ordovician are conformable (Hintze et al. 1988; Miller et al. 2003; Miller and Evans 2012), faulting only later in the Jurassic due to compressional forces and in the tertiary due to block-faulting (Powell 1959). It also seems unfeasible to assume that multiple blocks, representing shallow, sub-tidal environments were pushed onto the edge of the Laurentian craton in a neat geometric arc that duplicates the shallow, sub-tidal environments of the craton itself (Fig. 8). This latter scenario would suggest a "fluke" of gigantic proportions. An allochthonous interpretation for the microbialites becomes even less convincing when considering a global perspective; are we to assume that the microbialites in Cambrian deposits around the world also represent allochthonous environments (Fig. 9)?

\section{B. Abiotic Solution}

Were these upper Cambrian microbialites formed under strictly abiotic conditions? Although bacterial fossils have not been found in these microbialites, it is unlikely that strictly chemical, abiotic processes were responsible for their formation (Grotzinger and Rothman 1996; Ibarra and Corsetti 2016). Even so, there is ample evidence for the biogenicity of other kinds of encrusting organisms such as sponges (Coulson and Brand 2016). Even if a purely abiotic mechanism were responsible, this does not alleviate the problem. The crux of the issue is not biotic vs abiotic, it is time (Purdom and Snelling 2013). In bed 9, for example, time-dependent processes were responsible for microbialite coalescence and elongation (Coulson et al. 2016). In bed 11, encrusting sponges constructed $30-70 \mathrm{~cm}$-high microbialites one lamination at a time. Yet 11 distinct beds exist in the Hellnmaria Member, with multiple more beds existing in the Red Tops and Lava Dam Members that sit stratigraphically above the Hellnmaria Member (Fig. 1). What biological and/or environmental, time-dependent factors might be found in these microbialites and/or beds?

\section{Seismic Solution}

Brand et al. (2012) proposed a seismic origin for these microbialites. The ecologic and environmental aspects imprinted within the microbialites themselves and within the microbialite beds, however, make such an interpretation strenuous. Consider the coalescent forms associated with bed 9 ; within this single bed, 
round microbialites can be seen fusing as one traverses up-section (Fig. 3). This process seems to culminate in the formation of strongly elongate forms found in the middle of the bed. Up-section another $20 \mathrm{~cm}$ and the strongly elongate forms then separate into round forms once more. This process of coalescence of round heads to form elongate forms can be found in modern microbialites (Logan 1961). In bed 11, encrusting sponges are intercalated between concave down micritic bands, strongly suggesting the presence of a complex ecosystem rather than seismically induced shapes. Finally, there is no modern analogue for a seismic interpretation. It is true that vibrations do produce repeating motifs given loose particles, but it seems unreasonable to assume the same process produced an areal distribution of microbialites covering $2600 \mathrm{~km}^{2}$. Modern microbialites, although different from these ancient forms, still have much in common and thus provide the best analogy from which to interpret the Hellnmaria microbialites.

If the microbialites did not originate within the Flood event itself, then the only other options are their growing in either the pre or post-Flood worlds. Placing them in the post-Flood world is problematic because of the thick, stratigraphic sequences that occur directly above the Cambrian strata. These sequences range from Cambrian all the way through to Pennsylvanian in age (Miller and Evans 2012). A post-Flood interpretation for the Cambrian strata would, therefore, warrant a post-Flood interpretation for these other sequences as well. Since the latter are continental in scope, a post-Flood interpretation is highly unlikely.

\section{The Best Solution}

It would seem the best solution is to interpret these microbialites in terms of the pre-Flood world. This interpretation, however, has many unsatisfactory elements, the most salient of which concerns the processes that formed the Great Unconformity. If these microbialites represent in situ, pre-Flood environments, then according to the law of superposition, the Great Unconformity must have formed prior to their growth, within the pre-Flood world. This interpretation is of course, not going to sit well with many creationists for at least three reasons: 1 . The universal erosive processes associated with the Great Unconformity fit well within a Noahic Flood model. 2. Placing the Great Unconformity within the pre-Flood world naturally entails other universal catastrophic processes outside of those associated with the biblical Flood narrative. 3. If the onset of the Flood of Noah did not occur at the Precambrian/Cambrian boundary, then when did it? These problems are weighty, and no simple answers are forthcoming, but here are some thoughts.

There is no biblical warrant for denying the possibility of regional, perhaps even global catastrophic processes at work within the pre-Flood world. The biblical record is simply silent on the issue. There is no reason to believe that the pre-Flood world was always a tranquil, serine and calm place. It may have been, but there is no biblical reason to support this conclusion, "For we know that the whole creation has been groaning together in the pains of childbirth until now" Romans 8:22, ESV. It has been argued that pre-Flood, regional and/or global flooding, was unlikely on the basis of Noah's invitation to the antediluvian population. Surely these people would have jumped at the chance to board the ark given obvious evidence of large-scale flooding? Yet most creationists today believe that the Garden of Eden and the human population existed at a high elevation (Snelling 2013). This likely means that the Garden of Eden was also restricted to a single, although large geographic location. Granting some people most likely moved away from the Garden of Eden, it is not a stretch to suggest that the majority of antediluvians were still located in that general vicinity. Cratonic flooding over continents thousands of miles away at low elevations was, therefore, most likely an unobserved phenomenon. Other objections center on the exceptional preservation of many Cambrian fossils. Surely this kind of preservation is the result of rapid burial during the Flood? Yet similarly preserved fossils found in the Cenozoic Green River Formation (Roehler 1992) have been interpreted by most creationists as post-Flood deposits. The criteria for exceptional preservation is rapid burial, not rapid burial in the Flood. The biblical record then, provides scientists and theologians alike with some measure of freedom as to the nature of the pre-Flood world. Since the Fall, geophysical forces may have progressively been pushing the earth's crust out of equilibrium, readying it for the Flood event itself, "on that day all the fountains of the great deep burst forth" Genesis 7:11, ESV. This means staccato-like pulses of regional to global catastrophic events could have been the new norm leading up to the Flood.

Another possibility places the Great Unconformity within the creation week. Many creationists have discussed the likelihood of catastrophic erosion and sedimentation associated with emergent land masses on Day 3 of creation week (Snelling 2008; Dickens and Snelling 2008; Dickens 2017). As irony would have it, the most serious objection to a creation week solution is the presence of Precambrian microbialites that lie stratigraphically beneath the Great Unconformity! Wise and Snelling (2005), for example, discuss the presence of in situ Precambrian microbialites within the Kwagunt Formation at Grand Canyon. These authors opted for a post creation-week, pre-Flood interpretation for these microbialites based on evidence that supported natural, secondary processes of growth. A creation-week interpretation was considered but rejected based on the presence of multiple microbialite horizons, "In the case of the Awatubi stromatolites, however, their creation in living state would require all the stromatolites stratigraphically beneath them to have been created as fossils (Wise and Snelling 2005, p. 22)." Purdom and Snelling (2013) have also grappled with the same dilemma, discussing the origin of Precambrian microbialites in general. They concluded that Archean microbialites most likely represent specially created structures that furnished the first carbonate platforms, much like trees were specially created to furnish the first soils. Microbialites that accreted and grew in the pre-Flood world, post creation-week, are now thought to be represented in Mesoproterozoic through Neoproterozoic strata.

It is important to stress that all Precambrian microbialites discussed in the literature to date lack any kind of metazoan components (unlike the Cambrian forms). At best, the literature emphasizes the role of cyanobacteria in constructing Precambrian microbialites (Bertrand-Sarfati and Awramik 1992). Others, however, have suggested that most Precambrian microbialites had an abiotic, purely chemical origin (Grotzinger and Rothman 1996). This distinction between Precambrian and Cambrian microbialites is not a generalization; the distinction is real, sharp and intriguing. 
In considering a creation-week origin for the Great Unconformity as well as Precambrian microbialites, it will be pertinent to first consider what we know, based on Scripture, of God's creative acts when natural law as we know it was either suspended or nonexistent.

\section{A. The Earth: A Good Place to Start}

When we consider the earth's core, mantle and lower crust, as they were created on Days 1 through 4 of creation week, we will most likely agree that they exist and operate today in much the same way as they did when they were first completed. This means that the way in which God initially assembled the earth as a system of countless parts, and the way in which those parts interrelate with each other, cross a boundary that extends from the supernatural of Days 1 through 6, to the space/time historical context of Day 7. As it turns out, God seems to have made the earth as a system of parts that were assembled and continue to function in anticipation of a universe that would operate according to natural physical laws. For example, the existence of a dense, molten iron/nickel core, a less dense rocky, silicate mantle, and a crust that is the least dense of all, makes perfect sense in a universe where gravity exists. In a world like this, particles such as iron and nickel should move from the crust to the core, leaving the less dense particles to take up the space in between. This in fact, is precisely what we see. Yet these processes are exceedingly slow in the realm of time and space as we know it today. Why would God supernaturally create a system of interrelating parts that anticipated slow and gradual processes? He could just as easily have created an earth where iron, nickel and other heavy elements were "created" at the surface, instead of at its center. Yet he did not do this. This is only one facet of countless processes such as magma-mixing, exsolution, isotope partitioning, fractionation, and many more, that seem to correlate very well with many aspects of modern geophysics. Yet as with the gravitational pull of heavy elements down to the earth's core, these processes seem to have been "built into" the original earth in anticipation of their continuing to operate in the space/time historical context of Day 7 and beyond. These facts caused John Baumgardner to write this (Baumgardner 2000, p. 78-79):

I am persuaded the geochemical data do strongly favor the conclusion the continental crust is the result of partial melting/differentiation processes through which much if not most of the rock material of the mantle has been cycled. In the framework of a literal understanding of Genesis 1, this implies to me God simply employed special means to accomplish these changes...To summarize the observations and conclusions given above [in the original article] which I believe are reliable, let me begin by affirming the present-day earth structure as deduced by [modern, secular] seismology as firm and trustworthy (emphasis mine).

This example should not really come as a surprise, since most creationists already agree that God acted in much the same way when forming and filling the earth with life. The creation of soil, for example, a process that takes countless years and involves both geological and biological components, was completed in just a single day. Plants and animals were also created as mature organisms. Even the deposition of km/thick strata, according to
Andrew Snelling, must have been achieved in just a few hours (Snelling 2008). And this seems to be an agreed viable position; if God brought forth the land in just a single day then erosion must have been extremely rapid and intense. Yet at today's rates it would take tens or hundreds of years for the finest of those sediments to settle out of the water column. How would the first organisms have lived in seas filled with muddy soup? How would photosynthesis have been possible? All of the above makes perfect sense given the functional necessity of a mature creation.

\section{B. Biblical Examples of Non-natural Maturated Processes}

We are not limited to the creation week as to biblical examples of similar supernatural events. In John 2, Jesus supernaturally turns ordinary water into drinkable wine. Perhaps the most intriguing statement in this passage comes from the master of the feast when he exclaims, "you have kept the good wine until now" John 2:10, ESV. Why did he say this? Because good wine must be fermented for longer periods of time. Jesus had not just created wine, he had created aged wine. If a scientist were to take a sample of that wine without being told where it came from, he would conduct his experiments and may conclude that the wine had been grown in a particular climate, at a particular geographical location, and under the stewardship of a particular wine maker over a certain period of extended time. Of course, these conclusions would be at odds with what actually occurred, especially given the time involved. A similar biblical example can be found in Numbers 17. In that account, we are told that Aaron's staff, nothing more than a dead stick, not only budded, but actually produced a small harvest of mature almonds overnight. Yet almond trees require a long period of immature incubation - upwards of 5 years, before a viable and economically mature crop of almonds can be produced. The origin of this crop of almonds is of course beyond the scope of normal science. Yet if this small crop of almonds were harvested and sent to a modern laboratory, what kind of predictable conclusions might one expect to find? Many other examples of these maturated processes can be found in the Bible; Moses turns a stick into a living, breathing snake (Exodus 4:3); the snake had a complete skeleton, brain, lungs, liver, heart, stomach, spleen, pancreas, testes, small intestine, kidneys and rectum, all of which from our perspective must have had antecedents. An investigator would likely assume that the snake had an embryonic origin, which itself derived from haploid gametes that came from a separate male and female snake. Jesus creates bread and fish on multiple occasions (Example: Matthew 14: 13 - 21); atrophied bones, muscles and organs are restored to the extent that modern doctors would not detect their original condition (John 5:9; John 9:6). Time-dependent abstract examples also exist; in Acts 3:1 - 10, for example, we are told that a man lame from birth is healed and thereafter able to walk. Yet this is a double miracle. The man was born lame. The ability to walk is both physical and learned. We all know that it takes many years for toddlers to master this ability, and much the same timeframe is required for adults who have had to relearn to walk after an accident. Yet this man in Acts was not only healed, he was somehow infused with a time-dependent, learned skill. Adam and Eve must have been infused with similar learned skills.

\section{A Model for the Growth of Precambrian Microbialites}

And so with these biblical observations, it is suggested that 
Precambrian microbialites could be incorporated into the rapidly deposited strata of Snelling (2008). According to Snelling, 150,000 feet worth of strata were supernaturally deposited during creation week (Snelling 2008, p. 29). A very basic sequential interpretation might look something like this: between Days 1 and 3, two major creative acts occurred: 1 . The land came into existence and 2 . The plant-world was created. Cyanobacteria could well be included within the creative acts of Day 3 and perhaps even Day 2 (Purdom and Snelling 2013). From a purely supernatural perspective then, microbialites were forming before the land received its final scouring by the oceans. After deposition of perhaps km/thick sediment, some of which now contained entombed microbialites, full-scale erosion of the land (the Great Unconformity) was completed just before the land was soiled and vegetated.

One apparent problem with this interpretation is evidence of environmental processes. For example, in one Proterozoic sequence of rocks, underwater channels filled with limestone breccia and herringbone, cross-bedded sandstones are found straddled between stromatolitic reefs (Young and Long 1976). These facies are best interpreted in terms of near-shore, tidally-influenced environments. Yet how can this be if they grew and were subsequently buried during creation week? I think it would be a mistake to invoke an artificial, non-process-related explanation. Some might object and put forward the wine that Jesus created. This wine was created without any process at all, right? The answer to that question is not as straight forward as it seems. Are we to assume that nothing was going on in the mind of God during the time that the water became wine? Certainly "something" was going on in God's mind. We don't know what that "something" was, but God somehow took numerous non-time-dependent factors like vine and grape type, in conjunction with time-dependent factors such as fermentation and created mature wine. This process is of course entirely different from that which is experienced in the normal world, but it is still process. It would be better to interpret miraculous events, then, as in some sense process-related. In other words, there was a sequential series of events that formed the wine, just as there was a sequential series of events that formed the microbialites, the breccia, and the herringbone cross-beds. These events may have occurred on the earth, in the mind of God, or at the interface between the two, but either way, they are real and not contrived. Not only are they real, they are also representative of time-dependent processes such as those discovered by modern wine-makers and geologists. We must begin to look at these creative processes much like the ones that formed the earth's core, mantle and crust. The way in which the earth was formed is highly informative for Christians. God created a complex system of parts with post-creative processes built in. It is thus suggested that the supernatural creative acts of God at creation would look exactly the same as if they had occurred in the space/time, historical context of the post-Adamic world. Since process binds all inanimate objects and events in today's world, God also brought each part of creation into being mirroring the very same processes.

\section{Some objections \\ A. Death before the fall}

One objection to the formation and subsequent burial of biological entities such as microbialites during creation week is that the death of the organism results from its being buried. Yet this objection rests entirely on the interpretive notion of "death." Many creationists have already argued that some kind of death was at work in God's good creation, precisely because without it, necessary processes involved in the breakdown of biological wastes, such as fruit skin or fallen leaves, could not occur (Turpin 2013).

\section{B. A God of the Gaps}

Rather than promoting a God of the Gaps argument, these ideas actually alleviate much in terms of them. If God mirrored space/ time processes, then we should treat every inanimate object and every system of inanimate objects in the universe as if they came into existence in the space/time historical context of today, thus using today's normal laws of physics to solve problems. Of course, from a Christian perspective, there are informed, revelatory limits. For example, if a Christian geochemist is studying the partitioning of isotopes in ancient mantle rocks (assumed to be specially created), he can do science just like any other secular scientist. Remember, he is assuming that God made these rocks, and the relationships that exist between them, in anticipation of real physical processes that would operate in the real world. One of the factors he must check, however, is the time involved. He can do this because God specifically told him how much time at today's values was involved. These two pieces of data are not at odds. They simply must exist side by side as do many other theological concepts such as the trinity and inspiration. Given these assumptions, the Christian geochemist can put forward legitimate predictions and test scientific hypotheses just as well as the secular geochemist.

\section{Where to place the pre-Flood/Flood boundary}

This is an exceptionally difficult consideration and the proposal provided here is merely my conjecture at this moment in time. It may be that much of the pre-Flood world was in fact covered in water. This then is in accord with the secular view of flooded cratons, and may mean that the Flood event was less destructive in deeper subtidal locations. On the other hand, exposed land masses would feel the full brunt of large bodies of water moving across their surfaces. It is proposed, therefore, that creationists should be looking for a divide in the rock record that separates marine deposits, such as limestones, from regional-scale terrigenous sedimentary sandstones and conglomerates. Such a divide seems to occur starting in Carboniferous/Permian rocks and continuing through the Mesozoic, with a depositional hiatus only occurring between the late Triassic and early Jurassic (Peters and Gaines 2012). Cenozoic deposits are also terrigenous, but they are local in scale. This is not a perfect divide, as some Mesozoic rocks contain limestones and some upper Paleozoic rocks contain sandstones, but it is a consistent observation. Terrigenous deposits, therefore, would be more consistent with Flood rocks than marine deposits should this pre-Flood/Flood boundary be adopted.

\section{Is God lying?}

If a glass of Jesus' wine were available for scientific enquiry today, we would find a set of relationships that exist between all the constituents of the wine. These relationships would most likely lead the investigator to conclude that the wine was made using normal time-dependent processes and ingredients. Why? Because as with the creation of the earth, God creates supernaturally 
created things mirroring the things that are created in the timehistorical context of everyday life; things like snakes, almonds, and bread. Investigating these relationships using modern scientific tools would, therefore, always bring the investigator to a wrong conclusion as to their origin. This doesn't mean God is lying. If God tells us beforehand where and how these objects came from, then it is up to us to believe him. Consider the miracle of the incarnation and the biological constituents of Jesus' DNA. Jesus is fully God, but he is also fully human (Hebrews 2:17). This means Jesus would have diploid somatic cells. If a biologist could run a test on Jesus' blood, the results would indicate a chromosomal blueprint that was biologically indistinguishable from any other human. For those who only look at things in the natural, this would indicate that Jesus was nothing more than a man. He was the product of the union of two haploid gametes just like everybody else. Looking at Jesus in terms of natural, biological processes will only lead to a natural origin. Does this mean God is lying about Jesus' virgin birth and divine nature? Of course not. Why? Because he told us these things, despite what the biological evidence might suggest. There is no difference between this, the greatest miracle of all time, and the one discussed by God in the early chapters of Genesis. Consequently, "by faith we understand that the universe was created by the word of God, so that what is seen was not made out of things that are visible" Hebrews 11:3, ESV.

\section{CONCLUSION}

The presence of in situ microbialites in upper Cambrian deposits around the world is problematic for Flood models that correlate the pre-Flood/Flood boundary with the Precambrian/Cambrian boundary. It seems more reasonable to propose that the Great Unconformity be associated with non-natural, maturated processes that took place during the creation week. Precambrian microbialites, and in fact Precambrian rocks in general, should also be viewed in terms of non-natural, maturated processes, that differ little with the way in which God created the earth, soil, plants and even man. Many other objections no doubt stem from the hypotheses proposed in this paper, but must wait until the full ramifications of these data are digested and re-examined.

\section{ACKNOWLEDEMENTS}

I would like to thank two reviewers for invaluable comments. I would like to thank Matt McLain, John Whitmore, Andrew Snelling and Sarah Maithel for healthy criticisms, good ideas and manuscript editing. I would like to thank John Whitmore for sacrificing large amounts of time editing the manuscript. And I would also like to thank my wife, Beth, for being there as I bounced ideas all around our house, car and wherever we happened to be!

\section{REFERENCES}

Aitken, J.D. 1967. Classification and environmental significance of cryptalgal limestones and dolomites, with illustrations from the Cambrian and Ordovician of southwestern Alberta. Journal of Sedimentary Petrology 37:1163-1178. http://dx.doi. org/10.1306/74d7185c-2b21-11d7-8648000102c1865d.

Austin, S. A., and K.P. Wise. 1994. The Pre-Flood/Flood Boundary: As Defined in Grand Canyon, Arizona and Eastern Mojave Desert, California. In Proceedings of the Third International Conference on Creationism, ed. R.E. Walsh, pp. 37-47. Pittsburgh, Pennsylvania: Creation Science Fellowship.
Baumgardner, J.R. 2000. Distribution of Radioactive Isotopes in the Earth. In Radioisotopes and the Age of the Earth, eds. L. Vardiman, A.A. Snelling, and E.F. Chaffin, pp. 49-94. Dallas Texas: Institute for Creation Research, and Chino Valley: Creation Research Society.

Bertrand-Sarfati, J., and S.M. Awramik. 1992. Stromatolites of the Mescal Limestone (Apache Group, middle Proterozoic, central Arizona): taxonomy, biostratigraphy, and paleoenvironments. Geologic Society of America Bulletin 104:1138-1155.

Berelson, W.M., F.A. Corsetti, C. Pepe-Ranney, D.E. Hammond, W. Beaumont, and J.R. Spear. 2011. Hot spring siliceous stromatolites from Yellowstone National Park: assessing growth rate and laminae formation. Geobiology 9:411-424.

Brand, L.R., S.E. Phillips, and A.V. Chadwick. 2012. Elongated stromatolite-like structures in the upper Cambrian Hellnmaria member, Notch Peak Formation, Utah. Geological Society of America, Abstracts with Programs 44, no. 7: p. 22.

Burne, R.V., and L.S. Moore. 1987. Microbialites: organosedimentary deposits of benthic microbial communities. Palaios 2:241-254.

Coulson, K.P., and L.R. Brand. 2016. Lithistid sponge-microbial reefbuilding communities construct laminated, upper Cambrian (Furongian) 'stromatolites.' Palaios 31, no. 7:358-370.

Coulson, K.P., L.R. Brand, and A.V. Chadwick. 2016. Microbialite elongation by means of coalescence: an example from the upper Cambrian of Utah. Facies 62, https://doi.org/10.1007/s10347-0160469-5.

Demicco, R.V. 1985. Platform and off-platform carbonates of the Upper Cambrian of western Maryland, U.S.A. Sedimentology 32:1-22. http:// dx.doi.org/10.1111/j.1365-3091.1985.tb00489.x.

Dickens, H. 2017. Colossal Water Flows During Early Creation Week and Early Flood. Answers Research Journal 10:221-235.

Dickens, H., and A.A. Snelling. 2008. Precambrian Geology and the Bible: a Harmony. Journal of Creation 22, no. 1:65-72.

Eagan, K.E., and W.D. Liddell. 1997. Stromatolite biostromes as bioevent horizons; an example from the Middle Cambrian Ute Formation of the eastern Great Basin. In Paleontological events; stratigraphic, ecological, and evolutionary implications, eds. C.E. Brett, G.C., and G.C. Baird, pp. 285-308. New York, Columbia University Press.

Gebelein, C.D. 1969. Distribution, morphology and accretion rate of recent subtidal algal microbialites, Bermuda. Journal of Sedimentary Petrology 39:49-60.

Grotzinger, J.P., and D.H. Rothman. 1996. An abiotic model for stromatolite morphogenesis. Nature 383:423-425.

Hintze, L.F., M.E. Taylor, and J.F. Miller. 1988. Upper Cambrian-Lower Ordovician Notch Peak Formation in Western Utah. United States Geological Survey Professional Paper 1393:1-29.

Ibarra, Y., and F.A. Corsetti. 2016. Lateral Comparative Investigation of Stromatolites: Astrobiological Implications and Assessment of Scales of Control. Astrobiology 16, no. 4:271-81. doi: 10.1089/ast.2015.1388.

Kennard, J.M., and N.P. James. 1986. Thrombolites and stromatolites: two distinct types of microbial structures. Palaios 1:492-503. http://dx.doi. org/10.2307/3514631.

Lee, J.-H., C.J. Sung, and S.K. Chough. 2015. The middle-late Cambrian reef transition and related geological events: A review and a new view. Earth-Science Reviews 145:66-84.

Logan, B.W. 1961. Cryptozoon and associate stromatolites from the recent, Shark Bay, Western Australia. Journal of Geology 69, no. 5:517-533. 
Miller, J.F., and K.R. Evans. 2012. The Great American Carbonate Bank in the Miogeocline of Western Central Utah: Tectonic Influences on Sedimentation. In great American carbonate bank: the geology and economic resources of the Cambrian-Ordovician Sauk megasequence of Laurentia, eds. J. Derby, R. Fritz, S. Longacre, W. Morgan, and C. Sternbach. American Association of Geologists memoir 98, pp. 769854.

Miller, J.F., K.R. Evans, J.D. Loch, R.L. Ethington, J.H. Stitt, L. Holmer, and L.E. Popov. 2003. Stratigraphy of the Sauk III interval (CambrianOrdovician) in the Ibex area, western Millard County, Utah and central Texas. Brigham Young University Geological Studies 47:23-118.

Oard, M.J. 2013. Raindrop imprints and the location of the pre-Flood/ Flood boundary. Journal of Creation 27, no. 2:7-8.

Osleger, D., and I.P. Montañez. 1996. Cross-platform architecture of a sequence boundary in mixed siliciclastic-carbonate lithofacies, Middle Cambrian, southern Great Basin, USA. Sedimentology 43:197-217.

Reid, R.P., P.T. Visscher, A.W. Decho, J.F. Stolz, B.M. Bebout, C. Dupraz, I.G. Macintyre, T.F. Steppe, and D.J. DesMarais. 2000. The role of microbes in accretion, lamination and early lithification of modern marine stromatolites. Nature 406:989-992.

Peters, S.E., and R.R. Gaines. 2012. Formation of the 'Great Unconformity' as a trigger for the Cambrian Explosion. Nature 484:363-366. DOI: 10.1038/nature10969.

Playford, P.E. 1980. Environmental controls on the morphology of modern microbialites at Hamelin Pool, Western Australia. Geological Survey of Western Australia. Annual Report:73-77.

Powell, K. 1959.The Geology of the Southern House Range Millard County, Utah, vol. 6. no. 1. Brigham Young University Research Studies: Brigham Young University.

Pratt, B.R. 1984. Epiphyton and Renalcis - diagenetic microfossils from calcification of coccoid blue-green algae. Journal of Sedimentary Petrology 54:948-971.

Purdom, G., and A.A. Snelling. 2013. Survey of microbial composition and mechanisms of living stromatolites of the Bahamas and Australia: Developing criteria to determine the biogenicity of fossil stromatolites. In Proceedings of the Seventh International Conference on Creationism, ed. M. Horstemeyer. Pittsburgh, Pennsylvania: Creation Science Fellowship.

Roehler, H.W. 1992. Description and correlation of Eocene rocks in stratigraphic reference sections for the Green River and Washakie
Basins, southwest Wyoming. United States Geological Survey. Professional Paper 1506-D:1- 82.

Saltzman, M.R., C.A. Cowan, A.C. Runkel, B. Runnegar, M.C. Stewart, and A.R. Palmer. 2004. The Late Cambrian SPICE ( $\delta 13 C)$ event and the Sauk II-Sauk III regression: new evidence from Laurentian basins in Utah, Iowa, and Newfoundland. Journal of Sedimentary Research 74:366-377. http://dx.doi.org/10.1306/120203740366.

Semikhatov, M.A., C.D. Gebelein, P. Cloud, S.M. Awramik, and W.C. Benmore. 1978. Microbialite morphogenesis-progress and problems. Canadian Journal of Earth Science 16:992-1015.

Snelling, A.A. 2008. Thirty Miles of Dirt in a Day. Answers Magazine (Oct.-Dec.):29-30.

Snelling, A.A. 2013. Were There Any Volcanoes, Mountains and Earthquakes before the Flood? In The New Answers Book, ed. K. Ham, pp. 279-288. Green Forest, Arkansas: Master Books.

Srinivasan, K., and K.R. Walker. 1993. Sequence stratigraphy of an intrashelf basin carbonate ramp to rimmed platform transition: Maryville Limestone (Middle Cambrian), southern Appalachians. Geological Society of America Bulletin 105:883-896.

Turpin, S. 2013. Did Death of Any Kind Exist Before the Fall? Answers Research Journal 6:99-116. https://assets.answersingenesis.org/doc/ articles/pdf-versions/arj/v6/death-before-fall.pdf

Wise, K.P., and A.A. Snelling. 2005. A note on the pre-Flood/Flood Boundary in the Grand Canyon. Origins 58: 7-29.

Yonkee, W.A., C.D. Dehler, P.K. Link, E.A. Balgord, J.A. Keeley, D.S. Hayes, M.L. Wells, C.M. Fanning, and S.M. Johnston. 2014. Tectonostratigraphic framework of Neoproterozoic to Cambrian strata, westcentral US: Protracted rifting, glaciation, and evolution of the North American Cordilleran margin. Earth-Science Reviews 136:59-95.

Young, G.M., and D.G.F. Long. 1976. Microbialites and basin analysis: an example from the upper Proterozoic of northwestern Canada. Palaeogeography, Palaeoclimatology, Palaeoecology 19:303-318.

\section{THE AUTHOR}

Ken Coulson graduated from Cedarville University with his BS in geology, and from Loma Linda University with his $\mathrm{PhD}$ in Earth Science. He also holds a BA degree in Christian Ministries from The Masters University. He currently teaches as an assistant professor of science at San Diego Christian College. He is married and has three daughters. 